\title{
Immunotoxic and Genotoxic Effects of Arsenic and Ameliorative Potential of Quercetin and Probiotics in Wistar Rat
}

\author{
Abeer Saeed Alahmari ${ }^{1,2,}$, Khadiga Gamal Eldeen Adham ${ }^{1,3}$, Ahmad Rashed Alhimaidi ${ }^{1}$ \\ ${ }^{1}$ Zoology Department, College of Science, King Saud University, Riyadh, Saudi Arabia \\ ${ }^{2}$ Biology Department, College of Science, King Khalid University, Abha, Saudi Arabia \\ ${ }^{3}$ Zoology Department, College of Science, Alexandria University, Alexandria, Egypt
}

Email address:

asaa-1404@hotmail.com (A. S. Alahmari)

${ }^{*}$ Corresponding author

\section{To cite this article:}

Abeer Saeed Alahmari, Khadiga Gamal Eldeen Adham, Ahmad Rashed Alhimaidi. Immunotoxic and Genotoxic Effects of Arsenic and Ameliorative Potential of Quercetin and Probiotics in Wistar Rat. American Journal of Life Sciences. Vol. 5, No. 4, 2017 , pp. 108-115. doi: $10.11648 /$ j.ajls.20170504.13

Received: July 8, 2017; Accepted: July 17, 2017; Published: August 11, 2017

\begin{abstract}
Arsenic is a significant environmental public health concern. The aim of the present study is to investigate the possible immunotoxic and genotoxic roles of arsenic and the ameliorative effects of quercetin and probiotics as natural antioxidants. This study was performed on male adult Wistar rats divided into six groups: control, $\mathrm{NaAsO}_{2}$-treated, quercetintreated, probiotic-treated, $\mathrm{NaAsO}_{2}$ and quercetin-treated, and $\mathrm{NaAsO}_{2}$ and probiotics-treated. Blood samples collected from all animals were prepared for some oxidative, immunological and genetic aspects. Administration of arsenic decreased body and spleen weight, reduced serum antioxidant defense parameters and DNA content, increased liver, kidney, and brain weights, plasma malondialdehyde (MDA), myeloperoxidase (MPO), and serum cytokines (IL-1 $\beta$, IL- 6 , TNF- $\alpha$ and IFN- $\gamma$ ). Adding quercetin to arsenic was effective in restoring the altered values of cytokines (IL-1 $\beta$ and IL-6), MPO, MDA, catalase (CAT) and reduced glutathione (GSH) induced by arsenic, whereas the presence of probiotics was effective in reducing genotoxicity and improving the changes of cytokines (TNF- $\alpha$ and IFN- $\gamma$ ) and superoxide dismutase (SOD). Quercetin and probiotics are excellent antioxidant therapies, through their ability to suppress reactive oxygen species ROS production, which may contribute to arsenic toxicity.
\end{abstract}

Keywords: Arsenic, Quercetin, Probiotics, Oxidative Stress, Lipid Peroxidation, Inflammation

\section{Introduction}

Arsenic (As) is a significant environmental public health concern worldwide, due to its wide distribution and increased hazard in humans and animals [1]. Since the middle of the $19^{\text {th }}$ century, production of heavy metals has increased steeply for more than 100 years, with concomitant emissions to the environment [2]. The primary route of As exposure for most of the population is by the ingestion of contaminated food or water and inhalation from contaminated sources. Most ingested and inhaled As is absorbed through the gastrointestinal tract and lungs into the blood stream and distributed to a large number of organs [3].
Toxic effects of As are mediated primarily by triggering the production of reactive oxygen species (ROS) leading to oxidative stress, lipid peroxidation, DNA damage, and alterations in cells' intrinsic antioxidant defenses [4] as well as the release of pro-inflammatory factors, including cytokines [5]. To evaluate oxidative stress and antioxidant defense, malondialdehyde (MDA), reduced glutathione (GSH), superoxide dismutase (SOD), and catalase (CAT) are normally determined [6]. However, myeloperoxidase (MPO) is an enzyme present in neutrophils and can be used as an indirect marker for inflammation and toxicity [7].

Quercetin is one of the most important bioflavonoids present in many fruits and vegetables [8]. It is considered an excellent antioxidant due to its ability to scavenge free 
radicals [9]. Few studies conclude that quercetin may provide a more effective therapeutic strategy in the management of As toxicity. In 2016, Baltaci et al. [10] suggested that quercetin has protective effects against As induced testicular damage by decreasing morphological damage, apoptosis, and oxidative stress. In addition, lipid peroxidation significantly suppressed and depleted antioxidant defense mechanisms that were restored by quercetin co-treatment [11].

Probiotics are live microbial fermented food dependent on high selection of lactic acid bacteria [12]. Probiotics have the ability to bind and detoxify some heavy metals [13]. This propriety could be a promising solution for heavy metal removal from water, liquid food, and from the body of humans and animals [14]. Besides heavy metal binding capacity, lactic acid bacteria also are known to have antioxidative properties, which may be another important characteristic for heavy metal toxicity protection [15].

Because of the extensive presence of $\mathrm{As}$ in the environment and its toxic properties, it is considered a hazardous environmental toxicant [16]. However, further studies are needed to reveal the potential roles and effectiveness of mitigating agents against its toxicity. Therefore, the present study was designed to investigate the possible in vivo immunotoxic and genotoxic roles of As in Wistar rats and the alleviative effects of two naturally occurring substances known for their potent antioxidant potential, namely quercetin and probiotic bacteria.

\section{Materials and Methods}

\subsection{Chemicals}

Quercetin was purchased from Jarrow Formulas Company (Los Angeles, California, USA). Probiotics were purchased from California Gold Nutrition Company (Perris, California, USA) in form of capsules, each containing $5 \times 10^{9}$ lyophilized cells of active probiotic strains, including Lactobacillus and Bifidobacteriumlactis. Sodium arsenite $\left(\mathrm{NaAsO}_{2}\right)$ and other chemicals were obtained from the Zoology Department- King Saud University, Riyadh.

\subsection{Animals and Experimental Design}

Adult male Wistar rats (150-180 g) were supplied by the animal house of Science College, King Saud University. The rats were transferred to wire-bottomed cages at the animal house. They were kept at an ambient temperature and fed on a special rodent diet supplied by Medical Professions for Veterinary Products and Fodders Additions Company. The rats were given fresh water through glass bottles with a capillary dropper fixed to the wall of the cage. Animals were divided into six groups $(n=15)$ and were orally treated by gastric tube for 4 weeks as follows: Group I control animals were given a $2 \mathrm{~mL}$ daily dose of distilled water; Group II animals received $\mathrm{NaAsO}_{2}$ daily at a dose of $5 \mathrm{mg} \mathrm{kg}^{-1}$ dissolved in water as the minimum dose that induces toxicity in the rats [17]; Group III animals received quercetin at a dose of $50 \mathrm{mg} \mathrm{kg}^{-1}$ dissolved in water [18]; Group IV animals were administered probiotic at dose of $2 \mathrm{~mL}$ containing $2 \times$ $10^{9}$ colony forming units (cfu) dissolved in water [19]; Group $\mathrm{V}$ and Group VI animals received $\mathrm{NaAsO}_{2}\left(5 \mathrm{mg} \mathrm{kg}^{-1}\right)$ and were treated orally with quercetin $\left(50 \mathrm{mg} \mathrm{kg}^{-1}\right)$ and probiotic $\left(2 \times 10^{9} \mathrm{cfu}\right)$, respectively.

\subsection{Physical and Biometric Measurements}

Weekly body weight gain and food intake measurements were recorded for each individual animal. At the end of the experimental duration, weights of liver, kidneys, spleen, and brain were determined.

\subsection{Toxicity Tests}

Arsenic accumulation in blood, liver, kidneys, and brain was determined by the atomic absorption spectrometry graphite tube technique [20].

\subsection{Biochemical Assays}

\subsubsection{Inflammation}

MPO activity was measured in plasma as a marker for inflammation [7] using a myeloperoxidase chlorination activity assay kit (Cell Biolabs, San Diego, USA).

\subsubsection{Immunotoxicity}

The concentration of cytokines (IL-1 $\beta$, IL- 6, IFN- $\gamma$ and TNF- $\alpha$ ) was evaluated in serum for estimation of the immunotoxic effect of As by Luminex assays using a Milliplex Map Rat Cytokine/Chemokine Magnetic Bead Kit (Millipore, Billerica, USA).

\subsubsection{Genotoxicity}

\section{i. DNA Quantitation}

DNA from rat blood was extracted using a DNeasy Blood Kit (Qiagen, Hilden, Germany). Quantitation of blood DNA was performed to determine the average concentration of DNA present in blood samples of control and other treated groups using Nanodrop technique [21].

ii. DNA Fragmentation Analysis

DNA fragmentation was analysed in blood using agarose gel electrophoresis to compare the degree of apoptosis among the experimental samples. Extracted DNA was separated on $1.5 \%$ agarose gels. Fragments were visualized after ethidium bromide staining [22].

\subsection{Lipid Peroxidation and Antioxidant Defence}

Lipid peroxidation (plasma MDA) and antioxidant defence (serum GSH, SOD, and CAT) parameters were measured by colorimetric assays using commercially available kits (Cell Biolabs, San Diego, USA) according to the manufacturer's instructions to evaluate oxidative stress and antioxidant defences [23].

\subsection{Statistical Analysis}

Statistical analyses for all data were performed using oneway analysis of variance (ANOVA) by SPSS 22. Statistical 
differences were considered significantly at $\mathrm{P} \leq 0.05$ levels by using Duncan's Multiple Range Test Procedure. Results were expressed as a mean \pm standard error (SE) of mean.

\section{Results}

\subsection{Changes in Body Weight Gain, Food Intake and Weights of Liver, Kidneys, Spleen, and Brain}

Administration of $\mathrm{NaAsO}_{2}$ led to a significant $(p>0.0001)$ decrease in body weight gain compared with control (Table $1)$. In contrast, the weight gain of both quercetin and probiotics treated groups were significantly $(p>0.01$ and $p>$ 0.001 , respectively) higher than corresponding control subject. In both $\mathrm{NaAsO}_{2}$ - quercetin and $\mathrm{NaAsO}_{2}$ - probiotics treated groups, the body weight gain was significant $(p>$ 0.0001 ) higher than the corresponding $\mathrm{NaAsO}_{2}$ treated group.

Regarding the food intake, no significant differences were seen in both quercetin and probiotics treated groups in comparison with control; whereas the treatment of $\mathrm{NaAsO}_{2}$ caused a significant reduction $(p>0.001)$ of food intake compared with control (Table 1). In both $\mathrm{NaAsO}_{2}$ - quercetin and $\mathrm{NaAsO}_{2}-$ probiotics treated groups, significant $(p>$
0.001) enhancement was found in food intake compared with the $\mathrm{NaAsO}_{2}$ treated group.

On the other hand, administration of $\mathrm{NaAsO}_{2}$ resulted in significant increase in the weight of liver, kidney, and brain ( $p>0.00001, p>0.0001$ and $p>0.0001$, respectively) compared with control, whereas the spleen weight was significantly reduced $(p>0.00001)$ (Table 1). However, quercetin treatment alone led to diminished liver $(p>0.01)$ and spleen $(p>0.001)$ weight compared with control. In contrast, no significant change was recorded in the weights of the kidney $(p>0.5)$ or brain $(p>0.430)$ compared with the control. When compared with the control, the administration of probiotics caused a significant $(p>0.001)$ decrease in the weight of the liver and spleen, and a slight drop $(p>0.5)$ in the weight of the brain was observed, whereas the weight of the kidney was slightly significantly $(p>0.05)$ increased. Compared to the $\mathrm{NaAsO}_{2}$ treated group, the addition of quercetin to $\mathrm{NaAsO}_{2}$ treatment caused improvement in the weight of the liver, kidney, and brain, whereas it did not affect the spleen weight. In addition, adding probiotics to $\mathrm{NaAsO}_{2}$ treated animals caused an ameliorative effect in the weight of the liver, kidney, spleen, and brain.

Table 1. Changes in body weight gain, food intake and organ weight of Wistar rats during the 4-week experimental period. Data are expressed as mean \pm SE of 15 animals.

\begin{tabular}{|c|c|c|c|c|c|c|c|}
\hline & & $\begin{array}{l}\text { Group I } \\
\text { (Control) }\end{array}$ & $\begin{array}{l}\text { Group II } \\
\left(\mathrm{NaAsO}_{2}\right)\end{array}$ & $\begin{array}{l}\text { Group III } \\
\text { (Quercetin) }\end{array}$ & $\begin{array}{l}\text { Group IV } \\
\text { (Probiotics) }\end{array}$ & $\begin{array}{l}\text { Group V } \\
\left(\mathrm{NaAsO}_{2}+\text { Quercetin) }\right.\end{array}$ & $\begin{array}{l}\text { Group VI } \\
\text { (NaAsO }+ \text { Probiotics) }\end{array}$ \\
\hline \multicolumn{2}{|c|}{ Body weight gain (gram) } & $61 \pm 3^{b}$ & $40 \pm 4^{\mathrm{c}^{* * * *}}$ & $71 \pm 2^{\mathrm{a}^{* *}}$ & $76 \pm 2^{\mathrm{a}^{* * *}}$ & $60 \pm 5^{\mathrm{b}++++}$ & $64 \pm 4^{\mathrm{b}+1++}$ \\
\hline \multicolumn{2}{|c|}{ Food intake (gram) } & $74.30 \pm 2.5^{b}$ & $65.25 \pm 2.91^{\mathrm{c}^{* * *}}$ & $74.48 \pm 4.10^{\mathrm{b}}$ & $74.92 \pm 3.08^{\mathrm{b}}$ & $77.52 \pm 3.72^{\mathrm{a}+++}$ & $79.86 \pm 4.1^{\mathrm{a}+++}$ \\
\hline \multirow{4}{*}{$\begin{array}{l}\text { Organ } \\
\text { weight } \\
\text { (gram) }\end{array}$} & Liver & $8.07 \pm 1.02^{b}$ & $10.39 \pm 1.15^{\mathrm{a}^{* * * * *}}$ & $7.94 \pm 0.20^{\mathrm{c} * *}$ & $7.84 \pm 0.12^{\mathrm{c}^{* * * *}}$ & $8.54 \pm 1.01^{\mathrm{b}++++}$ & $8.27 \pm 1.51^{\mathrm{b}+++++}$ \\
\hline & Kidney & $0.75 \pm 0.02^{\mathrm{c}}$ & $0.90 \pm 0.10^{\mathrm{a}^{* * * *}}$ & $0.75 \pm 0.03^{\mathrm{c}}$ & $0.79 \pm 0.12^{\mathrm{b}^{*}}$ & $0.85 \pm 0.01^{\mathrm{b}++}$ & $0.80 \pm 0.30^{\mathrm{b}+++}$ \\
\hline & Spleen & $1.01 \pm 0.05^{\mathrm{a}}$ & $0.75 \pm 0.12^{\mathrm{c}^{* * * * * *}}$ & $0.83 \pm 0.07^{\mathrm{b} * *}$ & $0.81 \pm 0.03^{\mathrm{b}^{* * *}}$ & $0.74 \pm 0.02^{\mathrm{c}}$ & $0.88 \pm 0.02^{\mathrm{b}+++}$ \\
\hline & Brain & $1.41 \pm 0.30^{\mathrm{bc}}$ & $1.71 \pm 0.02^{\mathrm{a}^{* * * *}}$ & $1.25 \pm 0.04^{\mathrm{c}}$ & $1.32 \pm 0.11^{\mathrm{c}}$ & $1.62 \pm 0.20^{\mathrm{b}++}$ & $1.65 \pm 0.21^{\mathrm{b}+}$ \\
\hline
\end{tabular}

Mean values in the same columns with different superscripts $(\mathrm{a}, \mathrm{b}$ and $\mathrm{c})$ differ significantly $(P \leq 0.05$, $\mathrm{n}=15)$. Asterisks indicate a significant difference in groups II, III and IV compared with group I, whereas plus signs indicate a significant difference in groups V and VI compared with group II.

\subsection{Arsenic Toxicity and Accumulation in Rat Tissues}

The alterations in brain, liver, kidney, and blood As accumulation are shown in Table 2. No significant differences were observed in the amount of As in the blood, brain, liver, and kidney of both quercetin and probiotics treated groups in comparison to the control. However, after treatment with $\mathrm{NaAsO}_{2}$, As content was remarkably ( $p>$ $0.00001)$ increased in blood and above organs. When animals received $\mathrm{NaAsO}_{2}$-quercetin, no significant changes were seen in As concentration in the brain or kidney compared with $\mathrm{NaAsO}_{2}$ treated rats, whereas As was significantly $(p>0.05)$ diminished in liver and blood. Furthermore, the addition of probiotics to $\mathrm{NaAsO}_{2}$ treated rats led to a significant drop in the As content in the brain $(p>0.01)$, liver $(p>0.01)$, kidney $(p>0.001)$ and blood $(p>0.01)$ compared with the $\mathrm{NaAsO}_{2}$ treated group.

Table 2. Changes in arsenic concentration (ppm) in brain, liver, kidney, and blood of Wistar rats during the 4-week experimental period. Data are expressed as mean \pm SE of 15 animals.

\begin{tabular}{|c|c|c|c|c|}
\hline & Brain & Liver & Kidney & Blood \\
\hline Group I (Control) & $0.52 \pm 0.02^{\mathrm{c}}$ & $0.73 \pm 0.09^{\mathrm{cd}}$ & $0.90 \pm 0.14^{\text {cd }}$ & $1.21 \pm 0.13^{\mathrm{cd}}$ \\
\hline Group II (NaAsO2) & $58.35 \pm 4.39^{\mathrm{a}^{* * * * * *}}$ & $116.55 \pm 15.11^{\mathrm{a}^{* * * * *}}$ & $169.57 \pm 23.40^{\mathrm{a} * * * * *}$ & $3411.36 \pm 127.04^{\mathrm{a}^{* * * * * *}}$ \\
\hline Group III (Quercetin) & $0.51 \pm 0.09^{c}$ & $0.72 \pm 0.05^{\mathrm{c}}$ & $0.91 \pm 0.09^{\mathrm{c}}$ & $1.20 \pm 0.11^{\mathrm{c}}$ \\
\hline Group IV (Probiotics) & $0.53 \pm 0.06^{\mathrm{c}}$ & $0.74 \pm 0.12^{\mathrm{c}}$ & $0.88 \pm 0.11^{\mathrm{c}}$ & $1.18 \pm 0.02^{\mathrm{c}}$ \\
\hline Group V (NaAsO2+Quercetin) & $56.89 \pm 2.16^{\mathrm{a}}$ & $93.34 \pm 4.56^{\mathrm{b}+}$ & $163.50 \pm 2.76^{\mathrm{a}}$ & $3003.88 \pm 58.87^{\mathrm{b}+}$ \\
\hline Group VI (NaAsO2+Probiotics) & $45.53 \pm 1.40^{\mathrm{b}++}$ & $87.65 \pm 3.87^{\mathrm{b}++}$ & $97.54 \pm 7.90^{\mathrm{b}+++}$ & $2978.38 \pm 49.81^{\mathrm{b}++}$ \\
\hline
\end{tabular}

Mean values in the same columns with different superscripts $(\mathrm{a}, \mathrm{b}, \mathrm{c}$ and $\mathrm{d})$ differ significantly $(P \leq 0.05$, $\mathrm{n}=15)$. Asterisks indicate a significant difference in groups II, III and IV compared with group I, whereas plus signs indicate a significant difference in groups V and VI compared with group II. 


\subsection{Biochemical Assays}

\subsubsection{Changes in Plasma Myeloperoxidase (MPO) Activities}

MPO was significantly $(p>0.00001)$ increased in the $\mathrm{NaAsO}_{2}$ treated group compared with the control (Table 3). Administration of quercetin or probiotics led to increased ( $p$ $>0.05)$ MPO activities compared with control. Adding quercetin to the $\mathrm{NaAsO}_{2}$ treated animals prevented elevation of MPO activities. In addition, the MPO activity in the rats receiving probiotics with $\mathrm{NaAsO}_{2}$ was significantly ( $p>$ 0.01 ) lower than the $\mathrm{NaAsO}_{2}$ treated group.

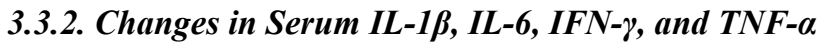 Concentration}

The administration of $\mathrm{NaAsO}_{2}$ resulted in a significant increase in the production of serum IL-1 $\beta(p>0.00001)$, IL-6 $(p>0.00001), \operatorname{IFN}-\gamma(p>0.00001)$, and TNF- $\alpha(p>0.0001)$ compared with the control animals (Table 3). In comparison to control, IL- $1 \beta$, IL- 6 , IFN- $\gamma$, and TNF- $\alpha$ concentrations were slightly elevated in rats fed quercetin but significant $(p$ $>0.05, p>0.001, p>0.05$ and $p>0.05$, respectively). The administration of probiotics did not significantly affect the amounts of IL-1 $\beta$, IL- 6 , and IFN- $\gamma$, whereas it led to a significant $(p>0.5)$ rise in the production of TNF- $\alpha$. When quercetin was added to $\mathrm{NaAsO}_{2}$ treated rats, IL-1 $\beta$, IL-6, and IFN- $\gamma$ concentrations were significantly diminished $(p>$ $0.0001, p>0.00001$ and $p>0.001$, respectively) in comparison to the $\mathrm{NaAsO}_{2}$ treated group, whereas no significant change was observed in TNF- $\alpha$ levels. Regarding the $\mathrm{NaAsO}_{2}$-probiotics treated group, the production of both IL-1 $\beta$, IL-6, IFN- $\gamma$, and TNF- $\alpha$ were significantly ( $p>0.001$, $p>0.0001, p>0.001$ and $p>0.05$, respectively) lower than rats treated with $\mathrm{NaAsO}_{2}$ alone.

Table 3. Changes in plasma Myeloperoxidase (MPO) activitiy and cytokines (IL-1 $\beta, I L-6, I F N-\gamma, T N F-\alpha)$ concentration of Wistar rats during the 4-week experimental period. Data are expressed as mean $\pm S E$ of 15 animals.

\begin{tabular}{|c|c|c|c|c|c|}
\hline & MPO (mU/mL) & IL-1 $\beta(p g / m L)$ & IL-6 (pg/mL) & IFN- $\gamma(\mathrm{pg} / \mathrm{mL})$ & TNF- $\alpha(\mathrm{pg} / \mathrm{mL})$ \\
\hline Group I (Control) & $1.839 \pm 0.019^{\mathrm{e}}$ & $51.05 \pm 6.14^{\mathrm{d}}$ & $813.45 \pm 11.74^{\mathrm{d}}$ & $868.82 \pm 10.11^{\mathrm{d}}$ & $17.64 \pm 2.01^{\mathrm{d}}$ \\
\hline Group II $\left(\mathrm{NaAsO}_{2}\right)$ & $2.045 \pm 0.036^{\mathrm{a}^{* * * * *}}$ & $79.25 \pm 2.95^{\mathrm{a}^{* * * * *}}$ & $1216.00 \pm 52.00^{\mathrm{a}^{* * * * * *}}$ & $1576.00 \pm 74.00^{\mathrm{a}^{* * * * * *}}$ & $28.13 \pm 2.50^{\mathrm{a}^{\mathrm{a} * * *}}$ \\
\hline Group III (Quercetin) & $1.899 \pm 0.014^{\mathrm{d}^{*}}$ & $58.62 \pm 2.83^{\mathrm{c}^{*}}$ & $949.12 \pm 12.21^{\mathrm{bc} * * *}$ & $988.17 \pm 12.20^{\mathrm{c}^{*}}$ & $21.29 \pm 1.90^{\mathrm{c}^{*}}$ \\
\hline Group IV (Probiotics) & $1.897 \pm 0.013^{\mathrm{d}^{*}}$ & $51.15 \pm 1.95^{\mathrm{d}}$ & $811.29 \pm 6.24^{\mathrm{d}}$ & $897.08 \pm 3.42^{\mathrm{d}}$ & $23.31 \pm 3.03^{\mathrm{b}}$ \\
\hline Group $\mathrm{V}\left(\mathrm{NaAsO}_{2}+\right.$ Quercetin $)$ & $1.946 \pm 0.035^{\mathrm{c}+++}$ & $61.90 \pm 2.50^{\mathrm{bc}+1++}$ & $923.30 \pm 9.01^{\mathrm{ct+1++}}$ & $1161.87 \pm 21.01^{\mathrm{b}+++}$ & $27.46 \pm 2.50^{\mathrm{a}++}$ \\
\hline Group VI ( $\mathrm{NaAsO}_{2}+$ Probiotics $)$ & $1.987 \pm 0.018^{\mathrm{b}++}$ & $67.82 \pm 3.55^{\mathrm{b}+++}$ & $986.83 \pm 5.30^{\mathrm{b}++++}$ & $1119.27 \pm 9.20^{\mathrm{b}+++}$ & $24.70 \pm 1.51^{\mathrm{b+}}$ \\
\hline
\end{tabular}

Mean values in the same columns with different superscripts (a, b, c, d and e) differ significantly $(P \leq 0.05, \mathrm{n}=15)$. Asterisks indicate a significant difference in groups II, III and IV compared with group I, whereas plus signs indicate a significant difference in groups V and VI compared with group II.

Table 4. Changes in DNA, Malondialdehyde (MDA), catalase (CAT), superoxide dismutase (SOD) and reduced glutathione (GSH) parameters of Wistar rats during the 4-week experimental period. Data are expressed as mean $\pm S E$ of 15 animals.

\begin{tabular}{|c|c|c|c|c|c|}
\hline & $\begin{array}{l}\text { Blood DNA } \\
(\mathrm{ng} / \mu \mathrm{I})\end{array}$ & $\begin{array}{l}\text { Plasma MDA } \\
(\mu \mathrm{M} / \mathrm{mL})\end{array}$ & $\begin{array}{l}\text { Serum CAT } \\
(\mathrm{U} / \mathrm{mL})\end{array}$ & $\begin{array}{l}\text { Serum SOD } \\
(\mathrm{U} / \mathrm{mL})\end{array}$ & $\begin{array}{l}\text { Serum GSH } \\
(\mu \mathrm{M} / \mathrm{mL})\end{array}$ \\
\hline Group I (Control) & $37.25 \pm 1.31^{\mathrm{a}}$ & $0.143 \pm 0.025^{\mathrm{b}}$ & $0.349 \pm 0.098^{\mathrm{a}}$ & $0.065 \pm 0.076^{\mathrm{a}}$ & $3.82 \pm 0.054^{\mathrm{b}}$ \\
\hline Group II $\left(\mathrm{NaAsO}_{2}\right)$ & $17.73 \pm 1.12^{\mathrm{*****}}$ & $0.391 \pm 0.098^{\mathrm{a}^{* * * * *}}$ & $0.242 \pm 0.034^{\mathrm{c}^{* * * *}}$ & $0.041 \pm 0.043^{\mathrm{c}^{* * * *}}$ & $2.94 \pm 0.091^{\mathrm{c}^{* * * *}}$ \\
\hline Group III (Quercetin) & $37.80 \pm 2.07^{\mathrm{a}}$ & $0.157 \pm 0.071^{\mathrm{b}}$ & $0.356 \pm 0.052^{\mathrm{a}}$ & $0.063 \pm 0.011^{\mathrm{a}}$ & $4.83 \pm 0.012^{\mathrm{a}^{* * * *}}$ \\
\hline Group IV (Probiotics) & $36.63 \pm 3.42^{\mathrm{a}}$ & $0.185 \pm 0.012^{\mathrm{bc}}$ & $0.322 \pm 0.021^{\mathrm{a}}$ & $0.067 \pm 0.043^{\mathrm{a}}$ & $4.35 \pm 0.018^{\mathrm{a}^{* * *}}$ \\
\hline Group V ( $\mathrm{NaAsO}_{2}+$ Quercetin) & $20.00 \pm 2.00^{b+}$ & $0.213 \pm 0.032^{\mathrm{c}+1++}$ & $0.295 \pm 0.013^{b++}$ & $0.055 \pm 0.019^{\mathrm{b}+}$ & $3.64 \pm 0.033^{\mathrm{b}++++}$ \\
\hline Group VI ( $\mathrm{NaAsO}_{2}+$ Probiotics $)$ & $20.50 \pm 3.01^{\mathrm{b+}}$ & $0.269 \pm 0.013^{\mathrm{d}+++}$ & $0.275 \pm 0.033^{\mathrm{b}+}$ & $0.058 \pm 0.024^{\mathrm{b}++}$ & $3.40 \pm 0.041^{\mathrm{b}+++}$ \\
\hline
\end{tabular}

Mean values in the same columns with different superscripts ( $a, b$ and $c)$ differ significantly $(P \leq 0.05, \mathrm{n}=15)$. Asterisks indicate a significant difference in groups II, III and IV compared with group I, whereas plus signs indicate a significant difference in groups V and VI compared with group II.

\subsubsection{Genotoxicity}

\section{i. Changes in Blood DNA Concentration}

Blood DNA content fluctuations are represented in Table 4. In rats fed $\mathrm{NaAsO}_{2}$, a significant $(p>0.00001)$ depletion was seen in DNA concentration compared with control. However, no significant changes were found in DNA content following treatment with quercetin or probiotics compared to control. The administration of quercetin or probiotics to $\mathrm{NaAsO}_{2}$ treated animals led to a slight increase in DNA content, which was significant $(p>0.05)$ when compared to the $\mathrm{NaAsO}_{2}$ alone treated group.

ii. DNA Fragmentation

Figure 1 illustrates DNA fragmentation analysed in blood using agarose gel electrophoresis. The DNA from control animals exhibited bands with integrity and a molecular weight greater than $1000 \mathrm{bp}$. DNA fragmentation increased in rats fed $\mathrm{NaAsO}_{2}$, shown by a smear pattern, which indicates DNA damage. However, the treatment with quercetin or probiotics alone did not affect DNA integrity. Animals that received $\mathrm{NaAsO}_{2}$-quercetin showed a slight improvement in DNA pattern. In addition, adding probiotics showed a slight 
reduction of DNA fragmentation induced by $\mathrm{NaAsO}_{2}$.

\subsection{Changes in Plasma Malondialdehyde (MDA) Concentrations}

Plasma MDA was significantly $(p>0.00001)$ increased in rats treated with $\mathrm{NaAsO}_{2}$ compared with the control group (Table 4). In both quercetin and probiotics treated groups, no significant change was observed in MDA compared with control. In both $\mathrm{NaAsO}_{2}$-quercetin and $\mathrm{NaAsO}_{2}$-probiotics treated groups, MDA concentrations were significantly $(p>$ 0.0001 and $p>0.001$, respectively) lower than the corresponding $\mathrm{NaAsO}_{2}$ treated group.

\subsection{Changes in Antioxidant Defense Activity}

Administration of $\mathrm{NaAsO}_{2}$ caused a significant $(p>$ 0.0001 ) decrease in serum SOD, CAT, and GSH parameters versus the corresponding control (Table 4). In both quercetin and probiotics treated groups, no significant $(p>0.5)$ changes were recorded in the activity of SOD and CAT compared with the control, whereas GSH concentration was significantly increased $(p>0.0001$ and $p>0.001$, respectively). However, quercetin and $\mathrm{NaAsO}_{2}$ treatment prevented the reduction of SOD $(p>0.05)$, CAT $(p>0.01)$, and GSH $(p>0.0001)$ levels compared with $\mathrm{NaAsO}_{2}$ treated rats. In addition, a significant recovery of $\operatorname{SOD}(p>0.01)$, CAT $(p>0.05)$, and GSH $(p>0.001)$ values was recorded in the presence of probiotics with $\mathrm{NaAsO}_{2}$.

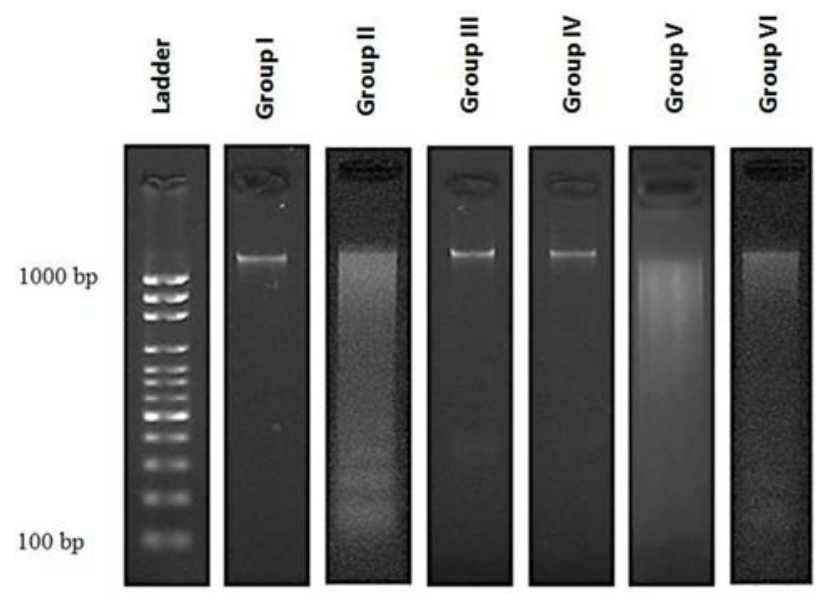

Figure 1. Agarose gel electrophoresis of DNA from the blood of Wistar rats during the 4-week experimental period. Experimental groups include group I (control, distilled water), group II (NaAsO $\mathrm{O}_{2}$-treated), group III (quercetintreated), group $\mathrm{IV}$ (probiotics-treated), group $\mathrm{V}\left(\mathrm{NaAsO}_{2}\right.$ and quercetintreated), and group VI (NaAsO $\mathrm{O}_{2}$ and probiotics-treated). Rats in all groups were given a $2 \mathrm{~mL}$ daily dose of the specified compound including distilled water, $\mathrm{NaAsO}_{2}\left(5 \mathrm{mg} \mathrm{Kg}^{-1}\right)$, quercetin $\left(50 \mathrm{mg} \mathrm{Kg}^{-1}\right)$, and probiotics $\left(2 \times 10^{9}\right.$ cfu).

\section{Discussion}

Arsenic is toxic and particularly known for alterations in biological pathways as well as inducing oxidative stress [24]. The results showed a decrease in the body weight gain of $\mathrm{NaAsO}_{2}$-treated animals, confirmed by the occurrence of a reduction in food intake as a result of the toxic effect of As.
The toxic effect of $\mathrm{NaAsO}_{2}$ is due to the ability of As to inhibit metabolism by altering the glucocorticoid hormonal system, which plays an important role in glucose regulation as well as carbohydrate, lipid, and protein metabolism [25].

$\mathrm{NaAsO}_{2}$ treatment led to a significant increase in the weights of liver, kidney, and brain. ICP-MS analysis of organ samples in our study showed the deposition of As in the above organs, which reflects As toxicity in those organs. Increased kidney weight could result from the methylation of As that was reabsorbed from the renal proximal tubules before it could be excreted in the urine [26]. The liver is known to concentrate As following exposure and play an important role in the metabolism of As, which may induce liver damage, thus identifying this organ as a target for As toxicity [27]. However, the increase seen in brain weight was due to the ability of small amounts of toxic metals that pass through capillaries and cross the blood-brain barrier causing neurotoxicity and edema [28]. The present work demonstrated a decrease in the weight of the spleen after treatment with $\mathrm{NaAsO}_{2}$. This finding disagrees with Dwivedi and Flora [29]. Reduction of spleen weight in the current study reflects a toxic effect of As which led to an alteration of oxidative stress-related indices and complex immunemodulatory effects causing a change in the responsiveness of spleen cells to apoptosis [30].

In the present study, the accumulation of As in the blood of the $\mathrm{NaAsO}_{2}$ treated rats was significantly greater than those in liver, brain, and kidney. A similar observation was reported by Lu et al. [31], who showed that blood is the main target for As. Rat haemoglobin showed higher affinity for As than human haemoglobin, and the retention time of As in the blood of rats is much longer than in the blood of other species. This is probably due to a large number of cysteine residues within the haemoglobin molecule [32].

The present biochemical investigations in the $\mathrm{NaAsO}_{2}$ treated group indicated significant elevation in plasma MDA and MPO values and reduction in CAT, SOD, GSH, and DNA parameters with DNA damage as typical signs of oxidative stress and lipid peroxidation induced by As [33] [34]. There is growing evidence indicating that arsenic toxicity is a hallmark of the excess generation of intracellular ROS, such as superoxide anion $\left(\mathrm{O}_{2}^{-}\right)$, hydroxyl radical $(\mathrm{OH})$, and hydrogen peroxide $\left(\mathrm{H}_{2} \mathrm{O}_{2}\right)$, which are responsible for oxidative damage and lipid peroxidation that play imperative roles in the biochemical alterations of cells [35]. Oxidative stress and resultant ROS may be involved in the damage of critical cell molecules, such as DNA [36]. Hydroxyl radicals tend to react with DNA bases to form adducts that lead to the formation of strand breaks and induce the release of metal ions, which contribute to DNA damage [36]. The significant decrease in serum CAT, SOD, and GSH by $\mathrm{NaAsO}_{2}$ proved the failure of the antioxidant defense system to overcome the influx of ROS production. $\mathrm{NaAsO}_{2}$-induced $\mathrm{MDA}$ production (a marker of lipid peroxidation) could be due to the impairment of cells' natural protective system [37]. Also, it is expected to increase MPO was caused by increased levels of $\mathrm{H}_{2} \mathrm{O}_{2}$ in the tissues [38]. 
In addition, $\mathrm{NaAsO}_{2}$ led to significantly increased serum levels of cytokines (IL- $1 \beta$, IL- 6 , TNF- $\alpha$, and IFN- $\gamma$ ). This observation is supported by Bashandy et al. [39], which found that production of inflammatory mediators are implicated in the pathogenesis of As-induced tissue injury in response to local inflammation. ROS are involved also in the promotion of inflammatory processes via activation of transcription factors, such as nuclear factor kappa-B (NF- $\mathrm{B})$ and activator protein (AP)-1, which induce the production of cytokines [40].

Regarding quercetin treatment, a significant increase was recorded in weight gain and food intake of rats treated orally by quercetin in agreement with Boots et al. [41]. This finding may be due to the potential role of quercetin as a food supplement for the enhancement of appetite and supported by general body health [42]. The current data does not record significant changes in the weight of liver, kidney, and brain as well as CAT, SOD, MDA, and DNA parameters after feeding with quercetin alone. This reflects the safe side of quercetin administration on the body. Nevertheless, It was noticed an increase in the weight of the spleen and the concentrations of MPO, GSH, and cytokines. Extended use of quercetin may cause the production of oxidation products, such as quercetin-quinone, which can result in slightly various toxic effects to the structure and function of some organs [43].

With the combined treatment of $\mathrm{NaAsO}_{2}$ and quercetin, quercetin enhanced DNA, CAT, SOD, and GSH parameters, in addition to reduction of both MDA and MPO toward the level of control animals. Above observation reflects the protective effect of quercetin against As-induced oxidative stress and lipid peroxidation. Within the flavonoid family, quercetin is the most potent ROS scavenger [44]. The antioxidative capacities of quercetin are attributed to the presence of two antioxidant pharmacophores within the molecule that have the optimal configuration for free radical scavenging, i.e. the catechol group in the B-ring and the $\mathrm{OH}$ group at position 3 of the AC ring [45]. Generally, the antioxidant efficacy of quercetin can be attributed to a high diffusion rate into membranes, allowing it to scavenge free radicals [46]. Also, quercetin was effective for suppressing the elevation of IL-1 $\beta$, IL-6, and IFN- $\gamma$ induced by As. Comalada et al. [47] confirmed this result by demonstrating that quercetin inhibits inflammation through the downregulation of the NF-kB pathway and lipopolysaccharide (LPS) induced production as well as the gene regulation of cytokines.

With regard to probiotics, the administration of probiotics alone showed no changes in body weight, food intake, and most biochemical parameters (DNA, CAT, SOD, MPO, IL$1 \beta$, IL-6, and IFN- $\gamma$ ). This finding is supported by several studies [48] [12], which reported that probiotics did not have any harmful effects on healthy rats. The above results reflect that using probiotics in a definite dose is proven safe for the body [49]. In contrast, some of results disagree with previous studies, where slight changes were found in the concentrations of MDA, GSH, and TNF- $\alpha$. The prolonged administration (30 days) of probiotics could be the reason for these small-observed changes [50].

In $\mathrm{NaAsO}_{2}$-probiotics treated rats, adding probiotics resulted in the reduction of As content in blood, kidney, liver, and brain. This observation agrees with improvement in body weight gain and food intake, in addition to ameliorating the weights of liver, kidney, spleen, and brain toward that of control animals. A previous report confirms these results indicating that probiotics have a protective role against the toxicity of heavy metals [48]. The findings showed that probiotic supplementation together with $\mathrm{NaAsO}_{2}$ led to diminished MPO, MDA, and cytokine (IL-1 $\beta$, IL-6, IFN- $\gamma$, and TNF- $\alpha$ ) levels as well as enhanced CAT, SOD, and GSH parameters and improved the DNA content and fragmentation pattern. Numerous studies have investigated the interaction of bacterial species with metals and their use to remove metals from contaminated sites, therefore inhibit ROS production, which contributes to oxidative stress, lipid peroxidation, and other toxic effects [51]. In addition, probiotics prevent $\mathrm{NF}-\mathrm{\kappa B}$ activation, which plays a pivotal role in the expression of inflammatory cytokines without any adverse effect on the viability of surrounding cells [52]. The surface of lactic probiotics is composed of a thick layer of peptidoglycan, proteins, and polysaccharides. Therefore, probiotic bacteria have a great number of different possible ligands, which help export metals out of the cell and subsequently reduce damage and oxidative stress to the organism [48].

\section{Conclusion}

This project determined that the use of quercetin and probiotics at a specific dose and for a certain duration is a great benefit for the inhibition of most As toxicity by suppressing ROS production and NF- $\mathrm{KB}$ activation, which is responsible for oxidative stress and inflammation. These findings push studies one step further toward using quercetin and probiotics for the therapeutic treatment of many diseases in the body.

\section{Acknowledgements}

This project was funded by the King Abdul-Aziz City for Science and Technology, Grant no. (T-1382093).

\section{References}

[1] Wang X., Mandal A., Saito H., Pulliam J., Lee E., Ke Z. and Shelton B. (2012) 'Arsenic and chromium in drinking water promote tumor genesis in a mouse colitis-associated colorectal cancer model and the potential mechanism is ROS-mediated Wnt/beta-catenin signaling pathway', Toxicol., Appl. Pharmacol., Vol. 262, pp. 11-21.

[2] WHO (World Health Organization) (2003) "Arsenic and Arsenic Compounds", 2nd ed. WHO Reg Publ Eur Ser., Geneva. 
[3] Akinleye S., Ebunoluwa O., Ademola A. and Olutayo T. (2015) 'Gastrointestinal protective efficacy of Kolaviron (a biflavonoid from Garcinia kola) following a single administration of sodium arsenite in rats: Biochemical and histopathological studies', Pharmacognosy Res., Vol. 7, No. 3, pp. 268-276.

[4] Liu S., Athar M., Lippai I., Waldren C. and Hei T. (2001) 'Induction of oxyradicals by arsenic: implication for mechanism of genotoxicity', Proc. Natl. Acad. Sci., Vol. 98, pp. 1643-1648.

[5] Cindrova-Davies T., Spasic-Boskovic O., Jauniaux E., Charnock-Jones D. and Burton G. (2007) 'Nuclear factorkappa $\mathrm{B}, \mathrm{p} 38$, and stress-activated protein kinase mitogenactivated protein kinase signaling pathways regulate proinflammatory cytokines and apoptosis in human placental explants in response to oxidative stress: effects of antioxidant vitamins', Am. J. Pathol., Vol. 170, No. 5, pp. 1511-1520.

[6] Ossola J., Groppa M. and Tomaro M. (1997) 'Relationship between oxidative stress and hemeoxygenase induction by copper sulfate', Arch. Biochem. Biophys, Vol. 337, No. 2, pp. 332-337.

[7] Klebanoff S., Kettle A., Nauseef W., Winterbour, C. and Nauseef W. (2013) 'Myeloperoxidase: a front-line defender against phagocytosed microorganisms', J. leukoc. Biol., Vol. 93, No. 2, pp. 185-198

[8] Salvamani S., Gunasekaran B., Shaharuddin N., Ahmad S. and Shukor Y. (2014) 'Antiartherosclerotic effects of plant flavonoids', Biomed. Res. Int., Doi: 10.1155/2014/480258.

[9] Liu C., Ma J. and Sun Y. (2011) 'Protective role of puerarin on lead-induced alterations of the hepatic glutathione antioxidant system and hyperlipidemia in rats', Food Chem. Toxicol., Vol. 49 , pp. $3119-3127$.

[10] Baltaci B., Uygur R., Caglar V., Aktas C., Aydin M. and Ozen O. (2016) 'Protective effects of quercetin against arsenicinduced testicular damage in rats', Andrologia, DOI: 10.1111/and.12561.

[11] Jahan S., Iftikhar N., Ullah H., Rukh G. and Hussain I. (2015) 'Alleviative effect of quercetin on rat testis against arsenic: a histological and biochemical study', Syst. Biol. Reprod. Med., Vol. 61, No. 2, pp. 89-95.

[12] Al-Damegh M., Zeitoun M. and Abdel-Salam A. (2014) 'The Role of Fermented Milk Containing Probiotic, Dandelion as Prebiotic or their Combination on Serum Metabolites, Enzymes, Testosterone and Testicular Histopathology of Arsenic Intoxicated Male Rats', J. Basic Appl. Sci., Vol. 10, pp. $492-503$.

[13] Monachese M., Jeremy P., Burton A. and Reid G. (2012) 'Bioremediation and Tolerance of Humans to Heavy Metals through Microbial Processes: a Potential Role for Probiotics?' Appl. Environ. Microbiol., Vol. 78, No. 18, pp. 6397-6404.

[14] Zhai Q., Wang G., Zhao J., Liu X., Tian F., Zhang H. and Chen W. (2013) 'Protective effects of Lactobacillus plantarum CCFM8610 against acute cadmium toxicity in mice', Appl. Environ. Microbiol., Vol. 79, No. 5, pp. 1508-1515.

[15] Watterlot L., Rochat T., Sokol H., Cherbuy C., Bouloufa I. and Lefevre F. (2010) 'Intragastric administration of a superoxide dismutase-producing recombinant Lactobacillus casei BL23 strain attenuates DSS colitis in mice', Int. J. Food Microbiol.,
Vol. 144, pp. 35-41.

[16] Akter K., Owens G., Davey D. and Naidu R. (2005) 'Arsenic speciation and toxicity in biological systems', Rev. Environ. Contam. Toxicol, Vol. 184, pp. 97-149.

[17] El-Demerdash F., Mokhtar I., Yousef M. and Radwan F. (2009) 'Ameliorating effect of curcumin on sodium arseniteinduced oxidative damage and lipid peroxidation in different rat organs', Food Chem. Toxicol., Vol. 47, pp. 249-254.

[18] Heeba G, Mahmoud M. and El Hanafy A. (2014) 'Antiinflammatory potential of curcumin and quercetin in rats: Role of oxidative stress, heme oxygenase- 1 and TNF-a', Toxicol. Ind. Health, Vol. 30, No. 6. pp. 551-560.

[19] Appleyard C., Cruz M., Isidro A., Arthur J., Jobin C. and De Simone C. (2011) 'Pretreatment with the probiotic VSL\#3 delays transition from inflammation to dysplasia in a rat model of colitis-associated cancer', Am. J. Physiol. Gastrointest. Liver Physiol., Vol. 301, pp. 1004-1013.

[20] Ninkova M., Aleksandrova A., Demeneskua J., Mirkov I., Mileusnic D., Petrovic A. and Kataranovski D. (2015) 'Toxicity of oral cadmium intake: Impact on gut immunity', Toxicol. Lett, Vol. 237, pp. 89-99.

[21] Desjardins P. and Conklin D. (2010) 'NanoDrop Microvolume Quantitation of Nucleic Acids', J. Vis. Exp., Vol. 45, pp. e2565.

[22] Sabine J., Hanne H., Sabine E., Hardt D., Fackelmayer F., Hesch R. and Knippers R. (2001) 'DNA fragments in the blood plasma of cancer patients: quantitations and evidence for their origin from apoptotic and necrotic cells', Cancer Res., Vol. 61, pp. 1659-1665.

[23] Wheeler C., Salzman J., Elsayed N., Omaye S. and Korte D. (1990) 'Automated assays for superoxide dismutase, catalase, glutathione peroxidase, and glutathione reductase activity', Anal Biochem., Vol. 184, No. 2, pp. 193-199.

[24] Agrawal S., Flora G., Bhatnagar P. and Flora S. (2014) 'Comparative oxidative stress, metallothionein induction and organ toxicity following chronic exposure to arsenic, lead and mercury in rats', Cell. Mol. Biol., Vol. 60, No. 2, pp. 13-21.

[25] Kaltreider R., Davis A., Lariviere J. and Hamilton J. (2001) 'Arsenic alters the function of the glucocorticoid receptor as a transcription factor', Environ. Health Perspect., Vol. 109, pp. 245-251.

[26] Hughes M., Kenyon E., Edwards B., Mitchell C., Razo L. and Thomas D. (2003) 'Accumulation and metabolism of arsenic in mice after repeated oral administration of arsenate', Toxicol. Appl. Pharmacol., Vol. 191, No. 3, pp. 202-210.

[27] Tyler C. and Allan A. (2014) 'the effects of arsenic exposure on neurological and cognitive dysfunction in human and rodent studies: a review', Curr. Environ. Health Rep., Vol. 1, No. 2, pp. 132-147.

[28] Gilani S., Zaidi S., Batool M., Bhatti D. and Mahmood J. (2015) 'Report: Central nervous system (CNS) toxicity caused by metal poisoning: Brain as a target organ Pak', J. Pharm. Sci., Vol. 28, No. 4, pp. 1417-1423.

[29] Dwivedi N. and Flora S. (2015) 'Sub-chronic exposure to arsenic and dichlorvos on erythrocyte antioxidant defense systems and lipid peroxidation in rats', J. Environ. Biol., Vol. 36, pp. 83-91. 
[30] Demenesku J., Mirkov I., Ivinkov M., Popov A., Zolotarevski L., Kataranovski D. and Kataranovski M. (2014) 'Acute cadmium administration to rats exerts both immunosuppressive and proinflammatory effect in spleen', Toxicol., Vol. 4, No. 326, pp. 96-108.

[31] Lu M., Wang H., Li X., Lu X., Cullen W., Arnold L. Cohen S. and Le X. (2004) 'Evidence of hemoglobin binding to arsenic as a basis for the accumulation of arsenic in rat blood', Chem. Res. Toxicol., Vol. 17, No. 12, pp. 1733-42.

[32] Shen S., Li X., Cullen W., Weinfeld M. and Le X. (2013) 'Arsenic binding to proteins', Chem. Rev., Vol. 113, No. 10, pp. 7769-7792.

[33] Gopalkrishnan A. and Rao M. (2006) 'Amelioration by Vitamin A upon Arsenic Induced Metabolic and Neurotoxic Effects', J. health sci., Vol. 52, No. 5, pp. 568-577.

[34] Shahid F., Rizwan S., Khan M., Khan S., Naqshbandi A. and Yusufi A. (2014) 'Studies on the effect of sodium arsenate on the enzymes of carbohydrate metabolism, brush border membrane, and oxidative stress in the rat kidney', Environ. Toxicol. Pharmacol, Vol. 37, No. 2, pp. 592-599.

[35] Gong X., Ivanov V., Davidson M. and Hei T. (2015) 'Tetramethylpyrazine (TMP) protects against sodium arseniteinduced nephrotoxicity by suppressing ROS production, mitochondrial dysfunction, pro-inflammatory signaling pathways and programed cell death. Arch', Toxicol., Vol. 89, No. 7, pp. 1057-1070.

[36] Kumar S., Yedjou C. and Tchounwou P. (2014) 'Arsenic trioxide induces oxidative stress, DNA damage, and mitochondrial pathway of apoptosis in human leukemia (HL60) cells', J. Exp. Clin. Cancer Res., Vol. 33, No. 42, DOI: 10.1186/1756-9966-33-42.

[37] Varghese M., Manju A., Abhilash M., Paul M., Abhilash S. and Nair R. (2014) 'Oxidative stress induced by the chemotherapeutic agent arsenic trioxide', Biotech., Vol. 4, No. 4, pp. 425-430.

[38] Banerjee M., Banerjee N., Ghosh P., Das J., Basu S., Sarkar A., States J. and Giri A. (2010) 'Evaluation of the serum catalase and myeloperoxidase activity in the chronic arsenic exposed individuals and concomitant cytogenetic damage', Toxicol. Appl. Pharmacol., Vol. 249, No. 1. pp. 47-54.

[39] Bashandy S., El Awdan S., Ebaid H. and Alhazza I. (2016) 'Antioxidant potential of Spirulina platensis mitigates oxidative stress and reprotoxicity induced by sodium arsenite in male rats', Oxid. Med. Cell Longev, DOI: $10.1155 / 2016 / 7174351$.

[40] Mittal M., Siddiqui M., Tran K. Reddy S. and Malik A. (2014) 'Reactive Oxygen Species in Inflammation and Tissue Injury', Antioxid. Redox. Signal, Vol. 20, No. 7, pp. $1126-1167$.
[41] Boots A., Li H., Schins R., Duffin R., Heemskerk J., Bast A. and Haenen G. (2007) 'The quercetin paradox', FEBS Lett., Vol. 222, pp. 89-96.

[42] Parmar S., Shah N., Kasarwala M, Virpura M., Shah K. and Patel P. (2011) 'Determination of quercetin by hptlc method present in zymodyne syrup-A poly herbal formulation', IJPSR., Vol. 2, No. 10, pp. 2724-2728.

[43] Çelik N., Vurmaz A. and Kahraman A. (2017) 'Protective effect of quercetin on homocysteine-induced oxidative stress', Nutrition, Vol. 33, pp. 291-296.

[44] Cushnie T. and Lamb A. (2005) 'Antimicrobial activity of flavonoids', Int. J. Antimicrob., Vol. 26, pp. 343-356.

[45] Heijnen C., Haenen G., Oostveen R., Stalpers E. and Bast A. (2002) 'Protection of flavonoids against lipid peroxidation: the structure activity relationship revisited', Free Radic. Res., Vol. 36, pp. 575-581.

[46] Moridani M., Pourahmad J., Bui H., Siraki A. and O'Brien P. (2003) 'Dietary flavonoid iron complexes as cytoprotective superoxide radical scavengers', Free Radic. Biol. Med., Vol. 34, pp. 245-253.

[47] Comalada M., Camuesco D., Sierra S., Ballester I., Xaus J., Gálvez J. and Zarzuelo A. (2005) 'In vivo quercitrin antiinflammatory effect involves release of quercetin, which inhibits inflammation through down-regulation of the NF-kappaB pathway', Eur. J. Immunol., Vol. 35, No. 2, pp. 584-92.

[48] Jama A., Mitić-Ćulafić D., Kolarević S., Đurašević S. and Knežević-Vukčević J. (2012) 'Protective effect of probiotic bacteria against cadmium-induced genotoxicity in rat hepatocytes in vivo and in vitro', Arch. Biol. Sci., Vol. 64, No. 3, pp. 1197-1206.

[49] Ouwehand A., Salminen S and Isolauri E. (2002) 'Probiotics: an overview of beneficial effects', A. Van Leeuw. J. Microb., Vol. 82, pp. 279-289.

[50] Tong J., Ran Z., Shen J., Zhang C. and Xiao S. (2007) 'Metaanalysis: the effect of supplementation with probiotics on eradication rates and adverse events during Helicobacter pylori eradication therapy', Aliment. Pharmacol. Ther., Vol. 25, No. 2, pp. 155-168.

[51] Shi X., Lindholm P. and Sarna S. (2003) 'NF-kappa B activation by oxidative stress and inflammation suppresses contractility in colonic circular smooth muscle cells', Gastroenterology, Vol. 124, pp. 1369-1380.

[52] Hegazy S. and El-Bedewy M. (2010) 'Effect of probiotics on pro-inflammatory cytokines and NF- $\kappa \mathrm{B}$ activation in ulcerative colitis', World J. Gastroenterol., Vol. 16, No. 33, pp. 4145-4151. 